\title{
Parliament for lawyers: an overview of the legislative
} process

\author{
by The Rt Hon The Lord Goldsmith QC
}

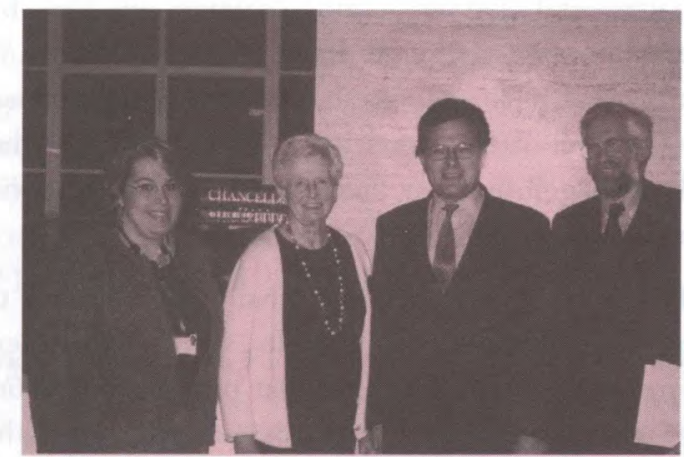

I to $r$ Dr Helen Xanthaki, Director, Sir William Dale Centre for Legislative Studies, IALS; Lady Dale; Lord Goldsmith QC; Professor Terence Daintith
The Second Annual Sir William Dale Memorial Lecture was given at Senate House, University of London, on 28 October 2002 by HM Attorney General, The Rt Hon The Lord Goldsmith QC. The lecture was organised by the Sir William Dale Centre for Legislative Studies at the Institute of Advanced Legal Studies, and is reproduced below.

legislative programme and there are very few Law Officers' Bills. I am however directly involved in legislation in three capacities:

(i) As a member of the Legislative Programme Committee, on which I have a special role in relation to the legality of Bills. I will say more about this Committee and my role later.

(ii) As adviser on issues relating to Bills. A lot of my advisory work is advising on issues such as potential incompatibility with convention rights of proposed legislation. Indeed, the Ministerial Code makes it clear that the Law Officers should be consulted where the departmental legal adviser is in doubt concerning the legality or constitutional propriety of legislation which the Government proposes to introduce.

(iii) In taking Bills, or parts of Bills, through the House of Lords. This arises both in cases where the subject matter of the Bill engages an area for which I am responsible as a Minister and where the Bill raises especially difficult legal issues. I was involved in the passage of :

- The Anti-terrorism, Crime and Security Bill, which was taken through all stages quickly in the wake of the events of September 11 .

- The Proceeds of Crime Bill, an extremely complicated and lengthy Bill running to over 460 clauses. 
- The Justice (Northern Ireland) Bill, which, among other things, made provision for a new Public Prosecution Service in Northern Ireland.

Let us step back before turning to the legislative process itself. The legislative process is not the end in itself, merely the means to the end. The end to which it is directed is the enactment of laws which are clear, concise and accessible, and the legislative process exists to assist Parliament to achieve that end. The Government is required to justify the merits of a Bill. The process subjects the Bill to an intense scrutiny to ensure it meets the Government's declared aims, and that it does so in as unambiguous a way as possible.

Let us not deceive ourselves that the debate about how to achieve the end, nor the success of the methods employed, is new. In 1726 Swift wrote of the work of Parliament "this society has a peculiar cant and jargon of their own that no other mortal can understand and wherein all their laws are written, which they take care to multiply" (Gulliver's Travels, 1726). Although the manner of expression may have changed somewhat, the concerns underlying Swift's comments are as pertinent today as they were when he wrote them.

Let us now turn to the process. I will break that process down for the purpose of my remarks into two stages: the drafting stage and the parliamentary stage. As with all attempts to place a schema over a process it runs the danger of delineating between the two stages too rigidly. More interestingly perhaps, it may also mask the growing development of a further stage of the legislative process between the two I have just mentioned. I will return to this later.

\section{DRAFTING STAGE}

A Bill is first and foremost the legal expression of a policy developed within a particular Government department. The task of translating that policy into a legal text is performed by a small group of highly skilled, highly specialised lawyers - the Office of Parliamentary Counsel. It has become fashionable to ask, "What did the Victorians do for us?" Well, one of the answers is that they gave us the Office of Parliamentary Counsel in 1869. It is part of the Cabinet Office and now numbers about 40 lawyers.

The fact that the office was not established until the latter part of the Nineteenth Century shows that the development of a specialised body of draughtsmen was not axiomatic. Indeed, I believe in many European systems today there is no comparable body of specialists. The office was created specifically to foster a tighter, less long-winded style of drafting. It has been said that its establishment ushered in a "golden age" of parliamentary draftsmanship (Lord Goodhart, HL Debate, December 10, 2001, HoL Hansard, col 1220). Whether there ever was a golden age is not something which need concern us here. But what is true is that a golden age only ever exists in hindsight and that in recent decades, certainly since the time of the valuable report of the Renton Committee, there is a perception that our legislative style has once again lost its way somewhat. All involved in the legislative process have an obligation to take steps to counter that perception. I have never heard any suggestion that is a reflection of the quality of the draftsman, and I am clear that that is not the case. I am convinced not only that the role they perform is a specialised one requiring a dedicated and highly skilled body of professionals, but also that they perform it admirably.

I have described their role as "translating the policy into a legal text". But rarely is the development of policy, preparation of instructions to Parliamentary Counsel by departmental lawyers, and drafting of the Bill a straightforward matter. It is an iterative process. When asked what instructions should contain Parliamentary Counsel will often answer, "explain the effect of the law today, and tell us what different legal effect you wish to achieve".

But determining precisely what legal effect is to be achieved involves considerable work. Parliamentary Counsel has a crucial role in that process in questioning and probing the policy - not to question the merits, but so as to be sure of the intended effects. It is only once this process is gone through that Counsel can turn to the task of how the legal effect is to be achieved - the drafting itself. Throughout the drafting process it is open to Parliamentary Counsel to raise matters with me concerning the drafting of a provision or its legality.

Let there be no doubt that, to be done properly and rigorously, this process takes time - often many months and the Bill which eventually sees the light of day will be the product of many drafts.

\section{LEGISLATIVE PROGRAMME COMMITTEE}

At this point, before the Bill is introduced into Parliament, it must be approved by the Legislative Programme Committee, a Cabinet Committee of which I am a member. This Committee advises the government on its legislative programme for the forthcoming session, gives authority for drafting Bills, and monitors the progress on Bills, as well as being the body which gives final authority for the introduction of a Bill into Parliament. It is a key body in the legislative process. Government Bills must be complete, and technically sound, when introduced. If a Government Bill requires a large number of technical Government amendments the legislative process risks becoming bogged down with getting the Bill into a fit state. While such amendments will inevitably be necessary, it is incumbent upon Government to keep them to a minimum.

The Law Officers have particular functions on this Committee in relation to the legality of Bills to be introduced. Firstly, the department responsible for the Bill 
is required to prepare a memorandum for the Committee dealing with the key convention issues raised by the Bill. I review these memoranda to ensure that they are legally sound. In addition, I may well have already been asked to advise on particularly difficult convention issues. Secondly, Parliamentary Counsel can bring points to my attention at this stage. Thirdly, there are certain matters on which, if they arise in relation to a Bill, the Law Officers are asked to advise. These include provisions which are intended to have retrospective effect, any "Henry VIII" clause (one giving power to amend primary legislation by secondary legislation) or any conferral of unusual powers. In addition, I am consulted on the commencement provisions of Bills.

It now seems unthinkable that the Government would not turn to its' Law Officers on such matters. However, things were not ever thus. Sir John Duke Coleridge, Attorney General in 1872, said that "law Bills are, generally, not always, initiated by the Lord Chancellor, and the Law Officers are by no means, as a rule, consulted upon them" (Parl Deb (3s) HC, vol 211, col 261, May 3, 1872).

\section{HUMAN RIGHTS}

I mentioned the human rights memorandum produced by the relevant department for LP Committee. This is just one aspect of the significant impact upon the legislative process made by the Human Rights Act (an Act which I may add in parenthesis has received much praise for the quality of the draftsmanship - see for example Lord Phillips of Sudbury, HL Hansard, December 10, 2001, col 1213)).

Before a Bill can be introduced into either House, the Minister responsible has to make a statement under s.19 of the Act that either he is satisfied that the Bill is compatible with the Convention Rights or that, although he is unable to make a statement of compatibility, the Government nevertheless wishes the House to with proceed with the Bill. This statement is printed on the front page of the Bill. Ministers have agreed to explain their view in relation to any particular provision of a Bill if asked during the passage of the Bill.

But this is not a bolt-on exercise at the end of the drafting process. Human rights considerations are at the heart of the policy consideration and the accompanying legal analysis. I am often called on to advise Ministers on the more difficult questions.

Another provision of the Human Rights Act which I would like to touch on briefly is s.3. That section establishes the new rule of statutory construction that, so far as it is possible to do so, legislation must be read and given effect in a way which is compatible with the Convention Rights. This is a powerful rule of interpretation, but I want to make it clear that the Government does not see section 3 as a drafting tool. We appreciate that clauses must continue to be drafted so that their intended effect is clear. It is simply not good enough to hide behind s. 3 when drafting legislation.

The Government must be clear in its intentions in relation to convention rights. To rely unduly on the courts' obligation under s. 3 to avoid potential incompatibility by reading down, or reading words into a statute, would undermine the principle of legal certainty. Furthermore, as Lord Nicholls in re $S$ in the House of Lords said in relation to s.3: "Interpretation of statutes is a matter for the courts, the enactment of statutes, and the amendment of statutes, are matters for Parliament" (see In re S and Others, HL, March 14, 2002, para. 39). The responsibility for passing Bills rests with the legislature, and consequently the effect of Bills must be clear to the legislators when they are asked to pass them.

I will mention shortly the role of the Joint Committee on Human Rights. I will simply say here that this body has a crucial role in ensuring proper scrutiny of Human Rights issues before Parliament. In addition the Government has since the beginning of this year been including in the explanatory notes published alongside Bills an account of the key convention issues raised in the legislation.

\section{PARLIAMENT}

The second stage of the process is of course the parliamentary process. Bismarck is reported to have said that "if you like laws and sausages, you should never watch either one being made", although I have failed to discover what set of circumstances could have prompted him to draw such an analogy. I do not wish hope to persuade you to visit a sausage factory, but I hope I may persuade you that Parliament is not necessarily a place that the squeamish should avoid.

A Government Bill may start in either House. The decision on this is largely driven by practical considerations, for example to ensure that both Houses have a balance of work. However, certain Bills, such as those which involve a considerable increase in public expenditure; may be thought more appropriately commenced in the Commons.

How long the parliamentary process takes is determined in the normal course of events by the combination of the conventions and standing orders of the Houses, which in some cases prescribe minimum periods between the various stages, and the demands on parliamentary time. An average Bill could spend three or four months passing through both Houses. However, the House can agree to accelerate the procedures in particular cases of urgency, and this was done for instance in the case of the Criminal Justice (Terrorism and Conspiracy) Bill, which took special measures in the wake of the Omagh bombing. This Bill went through all Commons stages on September 2, 1998 and all Lords stages the following day, but such acceleration of procedures is only contemplated in the most exceptional of circumstances. 
I do not propose to describe in detail the parliamentary stages: the first and second readings, Committee, report and third reading. For those who would like a detailed description of the stages they may find Parliament's own guide (available on its website) useful. But I do want to make some general observations about the purpose underlying them.

I will not claim that, if one were to start with a blank piece of paper, one would necessarily devise the procedures we have today. When thinking about the legislative process, and the improvements which might be made to it, I am reminded of the man who, when stopped in the street and asked for directions, replies "I wouldn't start from here if I were you". Well, we do start from here.

But to engage in some "blue sky thinking" for a moment, if one were to think of what procedures one would invent for the scrutiny of the Bill, I think it may well involve an opportunity for a debate on principles and broad themes; an opportunity for a detailed scrutiny of each provision, perhaps by a smaller group than the full House; and an opportunity to reconsider the whole Bill in the light of that detailed scrutiny. And that in a nutshell is the process we have. It is one which does allow for scrutiny of the detailed provisions of the Bill. Amendments are capable of being made, and often are, going to both substance and drafting, so the correct building blocks are in place.

I should also mention that during this process Parliamentary Counsel have an active role. They are involved with drafting of Government amendments and also in providing advice on the effect of opposition of amendments, as well as other matters. So, as I said earlier, the rigid two-stage schema is perhaps a little misleading.

Once the Bill has been passed by one House it is presented to the other House, and it goes through a largely similar process in the other place. But let me say to you that while the process is largely similar, the content does differ from House to House. This is in part due to those slight differences; I would here mention the absence of a guillotine in the Lords and, if I may be allowed to say so, a less tribal atmosphere. Also, the experience and expertise which is brought to bear on a Bill inevitably differs between the two Houses.

Now, because the Bill must be passed by both Houses, and both can make amendments to it, the Bill passed by the second House is rarely in exactly the same terms as the Bill passed by the first. There usually follows therefore a series of messages between the Houses seeking consent to the later amendments. If this is not resolved there is, in certain circumstances, the possibility of recourse to the Parliament Acts. We refer to this as "ping-pong," and there is the possibility that we will be engaging in some of this at the end of the current session. The final stage of the parliamentary process is Royal Assent to the Bill. In modern times this is a formality, and it has not been withheld since 1707 .

\section{TWO KEY PARLIAMENTARY COMMITTEES}

I would now like to mention briefly two important parliamentary committees. The first is the House of Lords Select Committee on Delegated Powers and Deregulation, chaired by Lord Dahrendorf. The second is the Joint Committee on Human Rights, chaired by Mrs Jean Corston.

\section{Delegated Powers Committee}

This Select Committee is concerned with the extent of legislative powers proposed to be delegated by Parliament to Ministers. The Committee is required to report to the House whether the provisions of any Bill inappropriately delegate legislative powers, or whether they subject the exercise of a legislative power to an inappropriate degree of parliamentary scrutiny. It takes evidence in writing from the department responsible for the Bill in the form of a memorandum submitted shortly after the Bill is introduced in the Lords.

The reports of the Committee are given considerable weight by all Members and by the Government. Indeed, it is rare that the Government does not accept the Committee's recommendations.

\section{Joint Committee on Human Rights}

I was fortunate enough to be a member of this Committee from January 2001 until the general election in that year, and I am sure that this will be a very important Committee in relation to human rights.

The terms of reference of the Joint Committee include consideration of matters relating to human rights in the United Kingdom (excluding consideration of individual cases). The Committee has made clear its intention to consider the compatibility with the convention rights of each Bill introduced. In the current session it has published 15 reports on Government Bills, as well as reports on draft Bills and two on remedial orders (we are currently in the happy position that there have to date been more reports by the Committee on remedial orders than there have orders).

The Committee has the power to call for evidence from persons and for papers. This gives it the power to raise points with the department responsible for a Bill as well seeking assistance from others. It tends to operate via written questions from the Committee's chair, acting on the advice of the Committee's expert adviser Professor David Feldman, to the Minister responsible for the Bill, raising very specific points about the compatibility of the Bill. I know from my own experience as a member of the Committee that the questions posed and the evidence submitted by departments in response are of the highest quality. I am convinced that the discipline of being required to answer questions by such a body can only serve to further focus departments' analysis of human rights. The Committee has also encouraged people and 
organisations outside Parliament to make submissions to it, and has encouraged Ministers to respond to the points made when it has thought them well founded. Again I think this can only enhance scrutiny of this important area.

The reports of the Joint Committee are held in very high regard by myself and my Ministerial colleagues. For example, the Anti-Terrorism, Crime and Security Bill was the subject of two reports by the Joint Committee (its Second and Fifth reports: Second Report, November 16, 2001, HL 43, HC 405; Fifth Report, December 5, 2001 , HL 51, HC 420). The Government made a number of amendments to the Bill as a result of these reports. An explicit requirement was introduced that the Secretary of State's belief that someone was an international terrorist and a threat to national security must be reasonable. The period of review for detainees was reduced from six to three months, amendments were made to the definition of international terrorist, and a sunset clause and annual review were introduced.

But the Government and Committee did not see eye to eye on all convention points raised by the Committee's reports on this Bill, and it seems to me that it may well be in such cases that the value of the Committee will be at its highest. Parliament when debating the relevant provisions will have available to it the reports of the Committee, which will include not only the Committee's analysis of the convention issue but also that of the department. The level of analysis available to the House will therefore be of an entirely different order to that which is possible in a normal debate on a Bill. I know the Committee members think that the increased transparency this gives the legislative process is one of the key benefits the Committee brings.

As well as being of assistance to Parliament, the reports may also be of assistance to the courts in certain circumstances. The reports of the Committee on the AntiTerrorism, Crime and Security Bill were referred to by the Lord Chief Justice in his judgment on the recent appeals concerning those detained pending deportation under the provisions introduced by that Bill (see $A, X$ and $Y$ and Others ${ }_{V}$ Secretary of State for the Home Department, judgment of the Court of Appeal of October 25, para. 63). While in that case they did not assist in determining the appeal, they could, for instance, where the evidence submitted to the Committee by the department, and the Committee's analysis of it, went to the question of the proportionality of a measure.

\section{A PERSONAL VIEW OF THE PROCESS}

After that thumbnail sketch, I would like to make a few personal observations on the process. Firstly, my experience has reinforced my view that the process does work so as to improve the substance and drafting of legislation. In the Justice (Northern Ireland) Bill I was able to bring forward amendments at Committee stage in relation to the Director of Public Prosecutions for Northern Ireland which addressed a particular point which had been raised by opposition members in the Commons (the first House) and by backbench Government peers in the Lords. The process allowed the point to be raised, the difficulties exposed and a suitable solution to be found.

Secondly, I am convinced the greater use being made of Grand Committee for committee stage in the Lords is a positive step. As you may know the House of Lords has recently agreed to certain modifications of its own procedures. This will reduce the number of hours available on the floor of the House for scrutiny of Bills. However, the Procedure Committee recommended (and the House has accepted) that this should be counterbalanced by greater use of Grand Committee.

Traditionally, committee stage is on the floor of the House, and subject to the usual procedures of such debates, including as to voting. Grand Committee takes place away from the floor of the House. Any peer who wishes to attend may do so, and so there is no question of any peer being excluded who wishes to attend. But the fact of being away from the floor of the House does, in my view, foster a different style of exchange, more akin to a dialogue than a series of speeches projected across the floor of the House. No votes are allowed in Grand Committee so amendments, whether tabled by Government or any other Member, can only be made if approved unanimously. This is subject to the convention that generally Government amendments are agreed to and opposition amendments are withdrawn. This ensures that the Bill at report stage reflects the Government's intentions. Again, I found the absence of voting had a beneficial effect on the conduct of the Committee. Clearly, when agreement cannot be reached, the House must vote. But voting does rather tend to bring with it its own rhythm and drama which can tend to get in the way of the proper scrutiny of detailed and technical provisions.

It also allows greater use to be made by a Minister of his officials. In Grand Committee officials will be sitting directly behind the Minister. When Committee is on the floor of the House, they are tucked away in a box to the rear of the Chamber and rely on the House officials a great deal in communicating with the Minister. There is no doubt in my mind that facilitating communications between the Minister and his officials has a beneficial impact upon the quality of the debate. Incidentally, I use the phrase "tucked away" advisedly since I am told the officials' box seems to have been constructed at a time when the average height of civil servants was a good deal less than it is today.

\section{PEPPER V HART}

A third matter which I would like to mention is the case of Pepper v Hart [1993] AC 593. This case is often referred 
to in the course of parliamentary debates on a Bill. In fact, thanks to the wonders of Parliament's excellent web site, I can tell you that a search on the exact phrase "Pepper v Hart" produces 5, 551 hits. Not all of those references to the case will have fallen into the error to which I will refer, but from my own experience it is safe to assume that a high proportion of them will do. In fairness, perhaps I should add that the errors in this regard are not confined to the opposition benches.

I am sure that you are all familiar with the judgment, which held that recourse could be had to Hansard in order to ascertain the meaning of a provision, but only in certain limited circumstances. The circumstances laid down by the House of Lords were:

(i) the legislation was ambiguous or obscure or led to an absurdity;

(ii) the material relied upon consisted of one or more statements by a Minister or other promoter of the Bill together if necessary with such other parliamentary material as was necessary to understand such statements and their effect; and

(iii) the statements relied upon were clear.

Despite the careful terms of the judgement, the case has been seen by some as a green light to raid Hansard for helpful ministerial statements as to the meaning of a provision. I think this is most unfortunate. While Hansard is a useful tool, the use of ministerial statements out of context to support particular constructions of a provision is, in most cases, unhelpful and in some cases positively misleading. I was therefore particularly pleased by the comments of the House of Lords in their recent decision in the case of Robinson (Robinson $v$ Secretary of State for Northern Ireland and Others, HL, July 25, 2002, in which I appeared for the Secretary of State for Northern Ireland. In that case, Counsel for Mr Robinson had sought to rely on statements made in a debate by Lord Dubs, the then Minister of State for Northern Ireland. The statements relied on were made in the middle of an exchange in which the Minister was repeatedly intervened on and asked numerous questions. None of the questions actually dealt with the specific issue which was the subject matter of the subsequent litigation, and Lord Dubs himself even expressed the hope that his answers be treated with some caution since he was being led into technical matters in the questioning. Nevertheless, much was sought to be made of the statements later in the litigation.

All five of their Lordships who heard the case made it clear that they found no assistance in the references to Hansard. Furthermore, they were clear that it would only be rarely that such assistance would be found. Lord Bingham said: "It is not surprising that a minister, called upon at very short notice to answer a number of unexpected points, failed to speak with the precision
Lord Hoffman added: "I am not sure that it is sufficiently understood that it will be very rare indeed for an Act of Parliament to be construed by a court as meaning something different from what it would be understood to mean by a member of the public who was aware of all the material forming the background to its enactment but who was not privy to what had been said by individual members (including Ministers) during debates in one or other House of Parliament (at para. 40).

Pepper $v$ Hart, and the need to go back to Hansard to elucidate the meaning of a provision, could be said to represent a failure of the legislative process. Our efforts should be on addressing that process to ensure that the Bills which receive Royal Assent are clear in their effect. I have mentioned already a number of procedures and innovations which I think are helping significantly in this. Before concluding I would like to comment on a few other innovations. The first is what I tentatively described as the beginnings of a new distinct stage in the overall process between drafting and the parliamentary stage. This putative stage has two components: public consultation and pre-legislative scrutiny by the House.

\section{PUBLIC CONSULTATION}

The Government entered office committed to put more Bills out to public consultation. With the exception of the Anti-terrorism, Crime and Security Bill, for obvious reasons, the Bills I have been directly involved with have been published for public consultation, along with their explanatory notes. In my view this is an extremely useful process. It allows experts outside Government to consider the legislation and make considered suggestions and observations. And it is a real process. On the Justice (Northern Ireland) Bill for example comments made by outside agencies and experts in child law prompted the Government to amend the Bill to ensure that important safeguards for children were not inadvertently jeopardised.

\section{PRE-LEGISLATIVE SCRUTINY}

The second innovation is pre-legislative scrutiny by a parliamentary committee. The Select Committee on the Modernisation of the House of Commons in its report of June 1997 (see "The legislative process", HC 190, 199798 ) indicated its wish to see a greater use of pre-legislative scrutiny, and the Procedure Committee in the Lords recommended (and the House accepted) that virtually all major Government Bills should as a matter of course be subject to pre-legislative scrutiny.

The process is one whereby a Bill is scrutinised prior to introduction by a committee of members. I think the process can provide an opportunity for a considered examination of a Bill's provisions. For example, the Committee can invite experts to give evidence on aspects of the Bill - I believe this was a course adopted in relation to the Freedom of Information Bill. A proper process of 
pre-legislative scrutiny could allow issues on particular aspects of a Bill to be thoroughly examined at a stage when it may be easier for the Government to reflect on points made and amend the Bill.

I am sure that a combination of these two innovations will have a beneficial impact on the quality of Bills introduced into Parliament.

\section{CONCLUDING REMARKS}

Swift's scathing views of Parliament were quoted earlier. I would venture to suggest that Swift would never be happy with the legislative procedures. While I would not suggest that they are perfect and cannot be improved, I do believe they are effective. But all parliamentarians should be ready to adopt new procedures if they will assist in the goal of enacting laws which are clear, concise and accessible.

There are some small, practical steps which can be taken to assist in this. I know many favour greater use of keeling schedules. These would show how a piece of legislation would look if amendments made to it in a Bill were passed. This is not a new innovation; I believe it was Neville Chamberlain when Prime Minister in 1938 who asked Parliamentary counsel to consider greater use of these. But they are of value, and I would like to see them used more often where they could be of benefit to parliamentarians and the public. In a similar vein, in a Bill with a large number of defined words, with those definitions being found in various clauses, I think an index of defined expressions is useful. This was done for instance in the Government of Wales Act, the Scotland Act, the School Standards and Framework Act and the Data Protection Act. Again, I think this simple device makes the Bill easier to use both for parliamentarians (which has a positive impact upon the quality of scrutiny) and the end user.

But many of the improvements we would like to see in scrutiny require more parliamentary time and the better targeting of parliamentary resources on the scrutiny of legislation. I have in mind the devotion of greater time to scrutiny and the greater use of consolidation Bills. This in turn depends on the modernisation of House procedures. The Government is committed to this. I have already mentioned the greater use made of the Grand Committee in the Lords; in the Commons, programme motions have been introduced to impose a discipline on the allocation of time to particular parts of Bills to ensure that the whole Bill is properly scrutinised. It is perhaps inevitable that there will be a period of adjustment as the House of Commons gets used to this new way of working. It is after all introducing a consensual element into what is an adversarial process. But the principle seems to me to be sound.

One further aspect of the modernisation of procedures which I would like to mention is the proposal that the rule that any Bill which has not completed every procedural stage falls in the autumn with the end of the Parliamentary Session be relaxed. A motion to provide for carryover of Bills is going before the House of Commons tomorrow. The rule as it stands distorts the work of Parliament. Governments fear to introduce a Bill after May as there is little prospect of it completing all stages by November. As a consequence there is a spate of Bills at the beginning of a Parliament and congestion in the legislative process. Clearly there needs to be a limit to how long a Bill can take to complete all stages, but this could be provided for in a different way. A relaxation of this rule would I think be of tremendous benefit to the legislative process.

\section{CONCLUSION}

I return to the goal: clear, concise and accessible legislation. Parliament has a duty to achieve that goal, and I think all in all the process is effective in assisting it to do that. The volume and complexity of legislation is increasing, and perhaps this is a reflection of the growing complexity in many areas of modern life. While we must always question the need for each Bill, each provision perhaps it is not realistic to expect that we can reverse the trend towards increasing complexity. Our challenge is to make sure the necessary innovations and reforms are made to ensure that Parliament, in the face of that growing complexity, continues to be able to discharge its duty to the public.

The Rt Hon The Lord Goldsmith QC

HM Attorney General 